\title{
Assimilados, régulos, Homens Novos, moçambicanos genuínos: a persistência da exclusão em Moçambique
}

"Assimilados", "régulos", "New Men", genuine Mozambicians: the persistance of exclusion in Mozambique

\section{Albert Farré}

\section{(2) OpenEdition Journals}

\section{Edição electrónica}

URL: http://journals.openedition.org/aa/1443

DOI: $10.4000 /$ aa. 1443

ISSN: 2357-738X

\section{Editora}

Programa de Pós-Graduação em Antropologia Social (UnB)

\section{Edição impressa}

Data de publição: 1 dezembro 2015

Paginação: 199-229

ISSN: 0102-4302

\section{Refêrencia eletrónica}

Albert Farré, «Assimilados, régulos, Homens Novos, moçambicanos genuínos: a persistência da exclusão em Moçambique», Anuário Antropológico [Online], v.40 n.2 | 2015, posto online no dia 01 junho 2018, consultado o 28 abril 2021. URL: http://journals.openedition.org/aa/1443 ; DOI: https:// doi.org/10.4000/aa.1443

\section{@(@) $\Theta \Theta$}

Anuário Antropológico is licensed under a Creative Commons Atribuição-Uso Não-Comercial-Proibição de realização de Obras Derivadas 4.0 International. 


\section{Assimilados, régulos, Homens Novos, moçambicanos genuínos: a persistência da exclusão em Moçambique}

Albert Farré

$\mathrm{UnB}$

Encarregam dessa árdua e ingrata missão os Régulos. E que são os Régulos? Quem são os Régulos hoje? Autoridades de Comédia. De Comédia ou de pura Farsa porque são uns risíveis ratóes de quem o Governo se serve, a quem o Governo atormenta com obrigaçóes ... São portanto os Régulos os encarregados do "apanha" de trabalhadores "voluntários" para a indústria, para a agricultura e para tudo quanto apetece...

(João Albasini apud Borges Coelho, 2010:194)

Assim opinava sobre os régulos João dos Santos Albasini (1876-1922), editorialista do jornal $O$ Brado Africano. Por ser mestiço, Albasini foi considerado um assimilado, mas sempre rejeitou tal condição por considerar-se simplesmente português, além de monárquico. Albasini foi talvez o jornalista com maior domínio da língua portuguesa no Moçambique das primeiras décadas do século XX (Margarido, 1988), o que em parte explica a admiração dos seus contemporâneos. Para além das suas qualidades jornalísticas, a sua vida privada é interessante: um misto de intelectual português e dandy britânico, de prosa agressiva e vestuário elegante, empresário e sentimental, o seu percurso vital mostra as inúmeras ambiguidades e contradiçóes do contexto colonial.

Albasini era membro de uma das famílias crioulas habituadas à mediaçáo comercial com os portugueses, e a boa situação do seu grupo social começou a mudar depois da conquista militar portuguesa do sul de Moçambique, iniciada em 1895. As três primeiras décadas do século XX foram péssimas para as famílias influentes da baía de Lourenço Marques. Enquanto se ia erguendo o novo Estado colonial, de concepção claramente metropolitana, aumentava a marginalização dos naturais de Moçambique, já fragilizados pelo regime republicano estabelecido em 1910. O Estado Novo, então, consolidou e refinou a grelha de privilégios e exclusôes sociais esboçadas pela República.

Falecido em 1922 de tuberculose, Albasini ficou esquecido durante muitas décadas (Silva, 2007). Só após a independência alguns historiadores se interessaram de novo por ele, como representante brilhante e contraditório de um grupo social em queda na nova capital de Moçambique. ${ }^{1} \mathrm{O}$ historiador moçambicano José Moreira (1997) tem focado nas queixas de Albasini sobre contradiçôes entre a 
lei dos assimilados de 1917 e o valor republicano da igualdade. Por outro lado, João Paulo Borges Coelho contrasta, no romance onde aparece a epígrafe deste artigo, a opinião negativa de Albasini sobre os régulos com a atitude do próprio Albasini nos convívios familiares, nos bairros das vizinhanças da cidade branca de Lourenço Marques. Finalmente, Jean Penvenne $(1989,1996)$ salienta o que se pode considerar uma das maiores contradiçôes de Albasini: ele, que nunca conseguiu estabelecer o jornal que dirigia como um negócio sólido, ganhava o seu pão como angariador de trabalhadores para as minas da União Sul-Africana. É verdade que, à diferença dos trabalhadores “apanhados" pelos régulos no interior da colônia de Moçambique, os trabalhadores com quem Albasini tratava iam com contrato. Contudo, no dia a dia do recrutamento de mão de obra para a poderosa Witswatersrand Native Labour Association (dita WENELA em Moçambique), que tinha exclusividade nos contratos para as minas, nem sempre era possível aplicar o princípio da dignidade humana ou o direito à civilização dos negros, ambos assuntos habituais nos explosivos editoriais de Albasini para

\section{$O$ Brado Africano.}

Portanto a obra, a vida, a posiçáo social de João Albasini representam uma série de contradiçóes típicas do colonialismo, com destaque para as relacionadas com a justaposição da exploração econômica (os regimes de trabalho) e da exclusão política (o estatuto jurídico de indígena) da maioria da população negra. Tal exploração e exclusão, além de se reforçarem mutuamente, estavam justificadas por uma supremacia racial e moral que colocava os europeus no topo da pirâmide social (Thomaz, 2002; Zamparoni, 2000).

Uma das características do colonialismo português em África foi a tentativa de compensar a fragilidade administrativa com uma profusão legislativa. Por outras palavras, como consequência tanto da falta de capitais como de outras fraquezas, escrever e aprovar leis era muito mais fácil que aplicá-las. Porém, a consciência que os próprios portugueses tinham dessa inflação de leis, que nunca seriam aplicadas de maneira sistemática, mas sim podiam ser usadas de forma arbitrária para favorecer interesses de portugueses particulares - e isso foi essencial no processo de ocupação do território (Direito, 2013; Farré, 2014b) —, contribuiu à constituição de um "olhar fragilizado" do português em África, em expressão de Trajano Filho (2004). Precisamente, uma das especialidades do jornalismo de Albasini foi denunciar a distância gritante entre as leis coloniais e as práticas coloniais; entre os princípios e valores consagrados pelas leis coloniais portuguesas, e os princípios e valores praticados pelos portugueses no dia a dia das colônias. 
A questão do trabalho e a questáo indígena - o chamado sistema de indigenato - são provavelmente os temas que, ao longo das décadas, têm criado um nó de contrassentidos maior. Não é estranho que sejam dois dos temas mais tratados e estudados sobre Moçambique, tanto durante como depois do colonialismo. ${ }^{2}$

$\mathrm{Na}$ década de 1990, depois de dezesseis anos de guerra, Moçambique viveu um período de grandes debates sociais. Um dos mais destacados foi, precisamente, o debate sobre a função dos régulos na estrutura do novo Estado multipartidário em construção. Outro debate, feito em paralelo, foi sobre a ideia de moçambicanidade: no novo contexto aberto pelos acordos de paz de 1992, com promessas de estabilidade, democracia e desenvolvimento, quem devia ser considerado cidadão moçambicano? Os dois debates levantavam questóes centrais sobre o passado, a tempo que retomavam uma polêmica antiga sobre o projeto de futuro para Moçambique. No pano de fundo desses debates havia muitas categorias sociais já "fora de prazo", alastradas pela inércia social e em permanente processo de reciclagem, mais ou menos consciente segundo o caso: estavam as categorias coloniais, estavam também as contracategorias com que o projeto revolucionário pós-independência tentou apagar, sem sucesso, as heranças do colonialismo; e estava, finalmente, a frustração de todos aqueles que confirmavam como, depois da brutal ingerência do apartheid durante a década de 1980, na década seguinte Moçambique era "apanhado" pela ingerência do humanitarismo ocidental, supostamente filantrópico. Muitos dos que sofreram a degradação da euforia pós-independência caíram no ceticismo, outros muitos caíram no cinismo: por trás das palavras bonitas sobre a democracia, via-se a cauda dos mesmos tubaróes de sempre, tanto no interior como no exterior de Moçambique. Assim, o filósofo moçambicano Severino Ngoenha (1993) concluiu: Moçambique podia ter conseguido a independência, mas a liberdade ainda estava longe.

Neste artigo, quero mostrar como os debates de Joáo Albasini, no início do século XX, e os debates do final do século XX mantêm umas mesmas temáticas, embora as palavras sejam, às vezes, diferentes. No meio ficam os percursos da experiência colonial. As diferenças entre um período e outro são os tipos de violência vividos durante os regimes políticos, assim como os ressentimentos, as frustraçóes e os oportunismos acumulados durante um século. No processo de mudança de um discurso de transformação social para o seguinte, os bricolages (Lévi-Strauss, 1971) feitos para superar os sucessivos passados tornam tudo muito mais confuso (Pina Cabral, 2000, 2002, 2004, 2005). ${ }^{3}$

As categorias de régulo, assimilado e indígena apareceram de novo nos debates dos anos 1990. Às vezes mostraram-se a olho nu, às vezes fantasiadas de diversas maneiras. Essa tríade de categorias delimitou, em certo modo, o campo semântico 
do colonialismo português. Durante a luta de libertação de Moçambique (19641974), a construção do Homem Novo foi, precisamente, uma tentativa consciente de escapar aos limites e às misérias daquele campo semântico (Cabaço, 2001, 2010; Macagno, 2009) para construir uma sociedade mais livre e mais justa. Aquela tentativa acabou fracassando, como é sabido, por uma confluência de fatores, entre eles a falta de empatia dos proponentes com o conjunto da população; ou a necessidade de improvisar às pressas um modelo social que estava só nas cabeças de alguns esclarecidos, sem esquecer as agressões que Moçambique recebia do exterior. Mas minha hipótese neste artigo não é tanto sobre por que falhou, senão sobre como falhou, e as consequências daquele falhanço. Proponho a seguinte hipótese: a maneira como o projeto revolucionário foi derrotado contribuiu para reforçar as heranças coloniais que ele pretendia apagar.

Apesar de os novos dirigentes moçambicanos terem explicitado uma vontade de ruptura com determinadas heranças coloniais - com destaque para a mentalidade colonial e as categorias a ela associadas - , e apesar de o partido no governo não ter mudado desde a independência, aquilo que foi explicitamente rejeitado acabou por ficar, e hoje continua sendo um elemento importante da sociedade moçambicana.

Pelo contrário, a categoria de Homem Novo, que foi a alternativa às categorias coloniais rejeitadas, e que representava a necessidade de criar um poder do povo numa nação unitária, não teve sucesso. A ideia do Homem Novo acabou por ser abandonada progressivamente na década de 1980, e hoje tem menos presença no imaginário social dos moçambicanos que as categorias coloniais de régulo, indígena e assimilado. Este artigo quer focar na derrota do projeto de Homem Novo, propondo que é na maneira como se tentou impor - excluindo - que encontramos algumas das causas do ressurgir das categorias coloniais.

Ora, para avaliar até que ponto a sociedade moçambicana pós-acordos de paz (1992) restaurou algumas das características do colonialismo, é necessário olhar para a evolução das categorias sociais ao longo do século XX.

\section{Sistema de indigenato: indígena, régulo, assimilado}

A partir das primeiras tentativas de revolução liberal em Portugal, começando pela de 1820 no Porto, a legislaçáo portuguesa sobre a cidadania adotou um pendor universalista e igualitário que também abrangia as colônias portuguesas. Claro que, durante o século XIX, a incidência das leis portuguesas em solo africano era quase nula. Naquele contexto, a equiparação das leis nos continentes tinha talvez muita potência abstrata, mas poucas consequências práticas. Em parte, esse movimento está ligado a certa compensação psicológica pela perda do Brasil (Lyra, 
1994). Foi só nos finais do século XIX que, à medida que os portugueses iam conseguindo o controle efetivo dos territórios africanos que acabaram por ficar sob sua soberania, a legislação colonial começou a ganhar mais complexidade.

Depois do ultimatum britânico de 1890, em Portugal tomou protagonismo uma nova geração de reformadores, militares e civis, ${ }^{4}$ cujo projeto era começar a reformar o Império pelas colônias africanas. Asseguravam que as conquistas e a posterior administração dos territórios africanos é que iriam transformar a metrópole, libertando-a dos círculos viciosos da política em Lisboa. Ora, para agir nas colônias era necessário que as leis abandonassem o nível de abstração absoluto para se aproximarem das realidades sociais africanas. Foi nesse contexto que a chamada geração do 95 necessitou imaginar como se organizavam as sociedades africanas (Macagno, 2001). O conjunto de normas e instituiçôes que, segundo eles, regiam as sociedades africanas foi chamado de usos e costumes. Note-se que, no processo de pensar os usos e costumes, se abandonou o universalismo prévio, e os súditos africanos foram diferenciados dos europeus. Simultaneamente todos os africanos foram uniformizados, pois compartilhavam a mesma diferença em relação à sociedade portuguesa: eram indígenas (Santos, 2005).

Até finais do século XIX, muitos dos termos usados pelos portugueses para se referirem aos africanos - tais como gentio, cafres ou cafraria — aludiam aos coletivos de que havia alguma notícia, geralmente mencionada por aventureiros, e com mais ou menos pormenor segundo o caso. Porém, essa tendência de acreditar em tudo que se ouviu começou a mudar quando o esforço de conquista militar passou a ser prioritário.

Assim, outra mudança importante dos reformadores da geração do 95 foi na maneira de olhar. Eles mudaram o foco: dos grupos africanos passaram para os indivíduos africanos, especificando as responsabilidades de cada um em relação ao projeto colonial português. $\mathrm{O}$ indivíduo africano passou a ser definido pela negação: um indígena era um indivíduo do território português que não era cidadão português, pois a ele era negado um nível de civilização suficiente para isso. Contudo, esse indígena teria de trabalhar para pagar o imposto, responsabilizando-se assim pelas despesas de uma colonização que, afirmava-se, iria civilizá-lo. Com base nesse pressuposto, foi-se refinando a doutrina do assimilacionismo português, baseada na tutela do Império sobre os indígenas africanos, até estes atingirem o nível de civilização exigível a um português "padrão".

A categoria de indígena diferenciada da do cidadão português pleno é consequência da tentativa de dar conta do contexto social africano desde uma metrópole que está, ela própria, experimentando mudanças profundas: os alicerces do Estado colonial são contemporâneos da queda da monarquia, em 
1910, e da queda da República, em 1926. Numa outra ocasião, usei a expressão "quebra-cabeças da legislação colonial portuguesa" para me referir aos impactos das peripécias políticas da metrópole nas colônias africanas (Farré, 2004).

A República portuguesa, apesar de imersa nas reviravoltas ideológicas entre laicos e integralistas, acabou por aprovar o Estatuto de Assimilado (1917), que era mais uma peça necessária do quebra-cabeça colonial. Se a condição de indígena estava principalmente referida àquelas populaçôes rurais ainda pouco afetadas pelos efeitos benéficos do contato com a civilização portuguesa — isto é, à maioria —, os assimilados seriam os indivíduos que, por viverem nas cidades, estariam já dando mostras de uma forma de vida mais próxima à portuguesa: no uso da língua, na aceitação da vida cristâ, na assunção do trabalho diário como forma de sustentar a família e na obediência às leis do governo, como as que se referem ao pagamento de impostos, ao serviço militar etc. Assim, a condição de assimilado seria a fase intermédia através da qual um indivíduo africano transitava da condição de indígena à de cidadão. Essa fase intermédia era obrigatória para todos os africanos, mas, na lógica da lei, os filhos de assimilado já seriam cidadãos plenos, por considerar-se que no processo evolutivo da civilização não havia volta (Santos, 2005).

Segundo os teóricos do colonialismo português, o corolário do assimilacionismo era claro e previsível: os indígenas estavam destinados a desaparecer. Isso tornarse-ia possível a longo prazo, quando já todos os negros tivessem se beneficiado da possibilidade do contato civilizador e, voluntariamente, aceitassem abandonar o modo de vida dos seus ancestrais para assumir as responsabilidades próprias do cidadão moderno. Entretanto, o governo colonial, ciente de estar a tutelar um processo de maturação $0^{5}$ complexo (Karlström, 2004), não tinha especial interesse em pressionar os seus tutelados. Em 1945, havia 1.845 assimilados em Moçambique, e uma década depois os assimilados eram 4.554 (Newitt, 1997).

O governo colonial não parecia estar muito preocupado com o ritmo lento do processo de assimilação dos indivíduos tutelados por ele. E mais: passou a compilar os usos e costumes das populaçôes indígenas, que teriam força de lei enquanto não se fosse assimilado. Os usos e costumes eram uma das peças mais antigas do quebra-cabeça, que continuava sendo necessária para não deixar no limbo jurídico a maioria da população. Entre os usos e costumes reconhecidos, destacava-se o fato de os africanos serem governados por um chefe único: o regedor ou régulo. ${ }^{6}$ Segundo se afirmava nos manuais coloniais, esse chefe concentrava em suas mãos toda a autoridade (jurídica, fundiária, administrativa). A ideia de que os africanos seriam governados por uma autoridade única foi comum aos principais impérios europeus em África (Farré, 2010). Mahmood Mamdani (1996) tem definido o 
tipo de administração colonial resultante como um despotismo descentralizado. Ora, no fundo de toda essa arquitetura legal destaca-se o problema do trabalho: a necessidade de grandes quantidades de máo de obra barata e a vontade de preservar diferenciadas as condiçóes de trabalho dos europeus e dos africanos (Cabaço, 2012; Harris, 1959; O’Laughlin, 2000; Zamparoni, 2012).

O Estado colonial fez de conta que empossava os chefes africanos como se fossem autoridades locais escolhidas pelas populaçóes. A realidade é que, regra geral, só eram empossados régulos após confirmação da sua subserviência ao Estado colonial. Embora os editoriais de Albasini já mostrassem, na segunda década do século $\mathrm{XX}$, que era problemático dizer que os régulos apontados pelo governo colonial representavam quaisquer usos e costumes locais, o discurso colonial português continuou afirmando, durante mais de seis décadas, que os régulos eram legítimos representantes dos indígenas e que o governo colonial só sancionava a sua eleição. ${ }^{7}$ As consequências dessa constante repetição foram notáveis na maneira de pensar o político em Moçambique, tornando-se especialmente visíveis quando, na década de 1990, se quis pensar a existência de um poder legítimo prévio ao Estado colonial em Moçambique (Dinerman, 1999; Farré, 2006; Geffray, 1990). Assim, muitos dos debates sobre o Estado em Moçambique na década de 1990 procuravam respostas à seguinte pergunta: tendo em conta a quebra de legitimidades que representou o fato de o regime colonial ter dado posse a tantos régulos, mais a bagunça feita pela Frente de Libertação de Moçambique (Frelimo) depois da independência, como o Estado pode agora recuperar a legitimidade perdida? (Farré, 2006).

Um dos últimos intelectuais portugueses dedicado a refinar, com primor jurídico, o discurso colonial português foi Adriano Moreira (1960). Foi ele quem preparou o último Estatuto do Indígena, aprovado em 1954, e curiosamente também quem o revogou, em 1961, quando foi apontado ministro do Ultramar. Apesar de ficar poucos meses no cargo, naquele ano especialmente conturbado para o regime salazarista (Simóes do Paço, 2008), Moreira teve tempo de aprovar um pacote legislativo que iniciava uma viragem importante na estratégia de justificação da colonização portuguesa (Cabaço, 2010).

A reforma feita por Moreira era recomendada desde havia tempo por determinados setores do regime salazarista, pois a distância entre a sociedade colonial e as leis coloniais já tinha atingido o nível do absurdo (Coissoró, 1965). Mas só com o início da luta armada em Angola é que a reforma foi adiante. Assumiu-se então, finalmente, que o quebra-cabeça da legislação colonial náo dava certo. Mesmo assim, algumas das peças foram conservadas para o futuro. 


\section{1: o fim do indigenato e a reformulaçáo dos régulos}

Em 1961, os estatutos de indígena e de assimilado desapareceram finalmente do quadro jurídico colonial. Se já não havia indígenas, todos os habitantes das colônias passavam a ser oficialmente cidadãos portugueses, tivessem ou não pedido, conseguido ou desejado a condição de assimilado. Assim, as leis regressaram aos princípios legais do século XIX, mas agora em condições sociais muito diferentes.

A ação do governo colonial em Moçambique, embora sempre precário e arbitrário na aplicação das leis, teve um impacto importante tanto na vida rural como no desenvolvimento das cidades, criando também grandes diferenças entre as regiōes de Moçambique. Sob a capa de uma legislação colonial unificada e de um império centralizado em Lisboa, o Estado colonial português despoletou diferentes experiências coloniais. Essa diversidade de experiências foi um dos principais problemas para unificar a luta de libertação em Moçambique (Borges Coelho, 2012; Cahen, 2010). Nem todos os que tinham queixas do governo colonial português compartilhavam o mesmo horizonte de expectativas segundo expressáo tomada de Stephen Toulmin (2001) - para o futuro de Moçambique. Além do mais, um dos objetivos da reforma de 1961 era aumentar o desentendimento entre os combatentes pela liberdade: os serviços de informação foram chamados à ação psicológica (Borges Coelho, 2012; Monteiro, 2014). Assim, os régulos ${ }^{8}$ e os assimilados — como camadas intermédias da sociedade colonial no campo e nas cidades respectivamente e, por isso, pessoas influentes num número de populaçáo bem maior — passaram a ser alvos de uma política de aliciamento destinada a garantir sua lealdade ao Império português.

De fato, a viragem da reforma de 1961 instituía um grande paradoxo: as categorias indígena e assimilado desapareceram das leis, mas os régulos, que na retórica oficial sempre estavam ligados aos usos e costumes dos indígenas, sobreviveram à reforma. Por quê?

Os régulos eram os interlocutores da administração colonial com a maioria da população rural. Portanto, num contexto de previsível guerra de guerrilhas, não se podia prescindir deles. Antes, pelo contrário, era melhor reforçá-los para garantir a lealdade das populações. Em suma, na nova estratégia colonial de ação psicológica, os régulos acrescentaram funçôes paramilitares e contrarrevolucionárias às funções administrativas, fundiárias e judiciais já conhecidas (Borges Coelho, 2012; Cabaço, 2010; Monteiro, 2014). Porém, já não era tão necessário argumentar que isso tudo era parte dos usos e costumes.

De fato, Moreira deu finalmente razão a Albasini, pois a reforma era um reconhecimento explícito de que as funçôes dos régulos coloniais sempre foram 
pouco tradicionais (O’Laughlin, 2000). ${ }^{9}$ Do ponto de vista do governo, os régulos deixaram de estar ligados à condição de chefes indígenas — pois já não havia indígenas - para ser uma peça-chave na luta contra os terroristas. ${ }^{10} \mathrm{~A}$ massa de população rural, que até 1961 estava excluída da cidadania portuguesa por não ser suficientemente civilizada, passava agora a ser um elemento estratégico fundamental, que era necessário integrar o mais breve possível (Moreira, 1960). Assim, enquanto no interior havia a crescente necessidade de recrutar soldados africanos, tanto pela falta de soldados metropolitanos como para contribuir com a africanização da guerra (Borges Coelho, 2012; Monteiro, 2014), no exterior, havia que mostrar evidências da vontade das populaçôes africanas de manteremse portuguesas, apresentando-as como um efeito óbvio do lusotropicalismo português (Castelo, 1999). O antigo assimilacionismo foi substituído por uma leitura particular da obra de Gilberto Freyre, de repente elevado às alturas pelas autoridades portuguesas e convidado a passear pelo império português para melhor "confirmar" suas teses (Macagno, 2012a; Thomaz, 2005).

Por outro lado, o crescimento econômico constante que Moçambique experimentava na década de 1960 permitia, pelo menos a uma parte da população, a percepção de certas melhoras no dia a dia. Essa tendência podia ajudar a convencer as populaçóes das vantagens de manterem-se portuguesas, sobretudo se as melhoras se apresentavam como se fossem a consequência direta da ação portuguesa. Porém, também podia ter efeito contrário, pois de fato o avanço econômico de muitos africanos foi travado para dar espaço às novas vagas de portugueses que chegavam da metrópole (Covane, 2001; Farré, 2015). O governo colonial pós-reformas de 1961 acrescentou a abrangência das próprias contradiçóes: a ação psicológica orientada a criar uma pequena elite africana que convencesse a população a não aderir à luta de libertação era contraditória com a política de enviar cada vez mais colonos portugueses para melhor lusitanizar o império (Adam, 2006; Castelo, 2004). Os privilégios concedidos aos colonos recém-chegados, nomeadamente na assignação de terra e crédito nos chamados colonatos, iam claramente contra a ascensão social dos africanos.

É importante sublinhar que a transferência de população branca da metrópole para as chamadas províncias africanas, principalmente Angola e Moçambique, teve um impacto diferente nas cidades e no campo. Essas diferenças ajudam a compreender a diferente evolução de assimilados e régulos depois de 1961. No campo, os régulos se beneficiaram mais do crescimento econômico de Moçambique, impulsionado em parte pelo aumento das necessidades alimentares das cidades. Essas melhorias econômicas ofereciam-lhes formas de refazer as teias sociais, em paralelo à lógica do Estado colonial (Harrison, 1998). Assim, 
podiam criar um espaço político próprio sem necessidade de confronto direto com o Estado colonial (João, 2000). ${ }^{11}$ De modo contrário, no mesmo período, os antigos assimilados das cidades sentiram-se cada vez mais prejudicados pelo regime colonial. Ali os privilégios dados a cada nova vaga de colonos brancos intensificavam a vivência da injustiça e alimentavam a politização e o ressentimento de alguns cidadãos negros, com destaque para os mais jovens e escolarizados (Cruz e Silva, 1990, 1999).

Assim, à medida que o colonialismo se prolongava, a experiência colonial da elite negra "assimilada" passou a ser cada vez mais diferente da experiência colonial da elite rural "tradicionalizada" à portuguesa. Em outras palavras, aqueles que moravam perto dos núcleos em expansão de colonos brancos sentiam muito mais de perto tanto o peso do racismo quotidiano como os efeitos da exclusão econômica: embora fossem de jure cidadãos portugueses, de facto nunca podiam competir com eles em pé de igualdade (Covane, 2001). Os régulos, pelo contrário, encontrando-se mais afastados dos colonos brancos, e sendo uma peça cada vez mais polivalente da administração - e da exploração - colonial, tinham um espaço de manobra bem mais amplo. A concorrência econômica direta dos régulos limitava-se a um ou outro cantineiro. ${ }^{12}$ Se é verdade que os cantineiros eram sistematicamente favorecidos pelo respetivo administrador de circunscrição, o isolamento em que viviam fazia com que, comparativamente com as cidades, a relação de forças fosse mais equilibrada (Teixeira, 2004). Aos poucos, os régulos foram encontrando mais possibilidades de acomodação política, e também melhor acesso aos lucros derivados da economia colonial que os assimilados nas cidades (João, 2000; Harrison, 1996, 1998; Farré, 2008).

A diferença da experiência colonial de régulos e assimilados tem muito a ver com a formação da Frelimo, e também com as dificuldades encontradas por ela para manter alianças sólidas com algumas autoridades africanas do interior.

Os desentendimentos produzidos pelo processo de africanização da guerra — ou antigos indígenas lutando pelo multirracialismo lusotropicalista e antigos assimilados lutando por uma nação moçambicana - serão um elementochave das duas guerras que Moçambique viveu antes e depois da independência conseguida em 1975: de 1964 a 1974 e de 1977 a 1992. Como aponta Borges Coelho, "há uma forte ligação entre o conflito colonial e a guerra interna que se seguiu na década de 80 , ligação essa cujos contornos mais precisos ainda estão por apurar" (2012:314). ${ }^{13}$ Essa ligação continua presente nos conflitos políticos ainda abertos mais de vinte anos depois da assinatura dos acordos de paz (Brito, 2014). 


\section{A Frente de Libertaçáo de Moçambique: a liderança de Eduardo Mondlane (1962-1969)}

Se, na segunda década do século XX, João Albasini exigia um lugar no projeto colonial para os negros civilizados, nos finais da década de 1940, Eduardo Mondlane já suspeitava que esse lugar podia não existir. De fato, rejeitou um cargo no Estado colonial de Moçambique argumentando a possibilidade de continuar os estudos nos Estados Unidos. Mondlane conseguiu estudar graças ao apoio das igrejas protestantes com presença no sul de Moçambique; e a estadia de dez anos nos Estados Unidos, de 1950 a 1960, lhe deu a possibilidade de consolidar seu pensamento político anticolonial (Cruz e Silva, 1999, 2001; Sansone, 2013).

O início das independências das colônias africanas em 1957, mais os massacres de Pidjiguiti em Bissau (1959) e de Mueda em Moçambique (1960), acabou por confirmar que não havia hipótese de reformar o colonialismo. Quando Mondlane visitou Moçambique, em 1961, era funcionário das Naçóes Unidas e já tinha o plano de formar uma frente para organizar a luta armada (Cruz e Silva, 1990, 1993). Alguns dos encontros com amigos que conseguiu fazer durante aquela visita derivaram em reunióes clandestinas onde conheceu novas pessoas que simpatizavam com sua visão, entre elas um enfermeiro de nome Samora Machel. Precisamente, Machel pertencia a uma família que havia perdido as terras irrigáveis à causa da constituição do colonato do Rio Limpopo (Ganhão, 2001). Além do mais, para conseguir tirar o curso de enfermagem, teve de aceitar entrar na igreja católica - ele pertencia a uma família protestante - e pedir o estatuto de assimilado. Mondlane acabaria por fundar a Frelimo em 1962 na Tanzânia, país que havia conseguido a independência no ano anterior. Uma frente expressava a vontade de reunir todos aqueles grupos de moçambicanos que, tanto no interior como nos países vizinhos, se opunham ao colonialismo português e, portanto, podiam concordar num mesmo fim: a libertação de Moçambique. O prestígio internacional de Mondlane - e seus contatos para conseguir bolsas de estudo nas universidades americanas - facilitaram essa confluência numa frente de libertação.

Ora, os diferentes percursos coloniais já referidos não pouparam desentendimentos entre os moçambicanos de diferentes procedências. Desde a sua fundação, em 1962, a vida interna da Frelimo foi bem conturbada, com constantes cismas. Muitos dos fundadores a abandonaram durante o primeiro ano de existência (Brito, 1988; Cahen, 2010; Opello, 1975), pois viram o suficiente para saber que aquilo não ia com eles. ${ }^{14}$

Os primeiros a abandonar a Frelimo foram alguns dos dirigentes dos grupos que já existiam em 1962, como a Udenamo (União Democrática Nacional de Moçambique), fundada na Rodésia do Sul (atual Zimbábue); a Manu (Mozambique 
African National Union), originada nas cooperativas Maconde, com fortes ligaçôes com a Tanzânia (inicialmente, Manu respondia a Makonde National Union); e a Unami (União Nacional de Moçambique Independente), fundada no Malawi (Brito, 1988, 2001). A maioria dos que saíram não concordaram com a distribuição de cargos feita no I Congresso da Frelimo. Portanto, logo no início era evidente que a liderança de Mondlane tinha suas limitaçôes, entre elas a falta de empatia necessária para criar uma frente que unisse as diferentes sensibilidades e lideranças.

Depois dos abandonos de 1962, a seguinte grande crise começou em 1967, e atingiu o momento mais crítico com o assassinato de Mondlane. Nessa fase, até quatro grupos conviviam dentro da Frelimo, cada um representando um percurso diferenciado até aderir à luta pela independência. Primeiro, havia os que fugiram do interior de Moçambique para se unir à Frelimo, na Tanzânia, como Samora Machel e Armando Guebuza. Depois havia os jovens que estavam a estudar na Europa e se uniram à frente, como Marcelino dos Santos ou Joaquim Chissano (Brito, 1988).

Depois estava Uria Simango, que foi pastor da igreja Congregacionista americana. Os missionários dessa igreja chegaram a Moçambique no século XIX, através da Rodésia do Sul, estabelecendo a primeira missão perto da foz do Rio Save. Nessa região, apareceu um ativismo cristão que se tornou político e anticolonial por uma via diferente do que estava acontecendo em Lourenço Marques e Inhambane, lugares de formação de Mondlane, e onde as igrejas presbiteriana suíça e metodista americana tinham mais presença (Cruz e Silva, 1999, 2001, 2004; Helgesson, 2002). De fato, o primeiro moçambicano a cursar estudos universitários na América provavelmente foi Kamba Simango, na segunda década do século XX. Kamba Simango também chegou aos Estados Unidos via África do Sul, graças às redes missionárias americanas, como Mondlane fez décadas mais tarde (Macagno, 2012b). Por outro lado, no início da década de 1950 houve fortes motins na foz do Rio Save (Machanga e Mambone), que Michel Cahen descreve como "uma região de forte anticolonialismo precoce" (2010:197). Portanto, Uria Simango, originário da mesma região que Kamba Simango, representava uma longa tradição de oposição ao colonialismo dos vandau de Moçambique (Florêncio, 2005).

Finalmente, havia os que ingressaram na Frelimo pela via das cooperativas agrícolas maconde (Adam, 1993; Adam \& Gentili, 1983; West, 2009). Uma vez começada a luta armada, em 1964, o planalto maconde, na fronteira com a Tanzânia, foi uma das frentes onde as zonas libertadas logo se estabilizaram. Durante os dez anos de guerra, cada vez mais homens maconde aderiram à Frelimo como guerrilheiros. 
A todos esses grupos, representativos de experiências coloniais diversas, devese acrescentar os indivíduos que foram ao encontro da Frelimo desde outras partes de Moçambique. Em suma, gerir toda essa diversidade não era fácil, ainda mais nas condiçóes precárias do exílio, e os conflitos foram constantes. Os motivos de conflito eram múltiplos, mas houve três com especial relevo: estudantes enviados pela Frelimo a estudar no estrangeiro que depois náo queriam combater pela libertaçáo (Opello, 1975); problemas do comando militar com as lideranças da Frelimo no interior de Moçambique — os chamados chairmen (Adam \& Gentili, 1983; Cahen, 2010); e, finalmente, desacordos pelo fato de militantes brancos ocuparem posiçóes relevantes dentro da Frelimo (Opello, 1975).

Segundo Correia (2015), outro fator que não ajudou a acomodar as diferenças no seio da Frelimo foi a tendência uniformizadora que Mondlane deu a Frelimo, e que acabou por ser uma das caraterísticas do pensamento da Frelimo até o presente. Em primeiro lugar, Mondlane afirmava que os moçambicanos estavam unidos pelo fato de serem todos colonizados pelos portugueses, o que lhes dava uma "experiência colonial comum" (Correia, 2015:94). Como tenho tentado mostrar, essa era uma afirmação problemática que, mesmo se tinha a intenção de consolidar um objetivo comum — acabar com o colonialismo português provavelmente acabou por fomentar mais conflitos internos. Em segundo lugar estava a pretensáo de que só a Frelimo representava o povo moçambicano, tirando a legitimidade de qualquer outro partido ou associação política (Correia, 2015). Também esse estilo de pensar tem continuado na Frelimo até os dias de hoje, embora exista um sistema multipartidário desde 1990 (Cahen, 2010; Brito, 2014).

De forma recorrente, os conflitos internos da Frelimo iam acompanhados de mortes acontecidas em circunstâncias pouco claras. Mesmo antes do assassinato de Mondlane, em 1969, outros dirigentes destacados da Frelimo faleceram em acidentes estranhos, como Felipe Samuel Magaia ou Casal Ribeiro (Cahen, 2010).

\section{A Frelimo sob a liderança de Samora Machel (1970-1986): o Homem Novo}

$\mathrm{O}$ assassinato de Eduardo Mondlane representou uma redução importante na diversidade de experiências reunidas na Frelimo. Uria Simango e Lázaro Nkavandame, representantes de duas dinâmicas de oposição ao colonialismo português, foram expulsos da Frelimo, acusados de estarem envolvidos na morte de Mondlane. As duas expulsóes coincidiram com a tomada do poder pelo setor que mais identificava a luta pela independência com uma revolução social. Essa sensibilidade que existia na Frelimo desde o início tornou-se hegemônica nos finais da década de 1960, coincidindo com a morte de Mondlane (Brito, 1988). 
Seu líder foi Samora Machel, que desde 1967 era o máximo responsável militar da Frelimo.Machel introduziu uma série de mudanças orientadas a garantir a unidade de ação na Frelimo. Essas mudanças iam ligadas a uma série de atitudes que redefiniram a natureza política da Frelimo (Brito, 1988, 2001; Cahen, 2010; Morosini, 1982). Em primeiro lugar, a supremacia do comando militar perante a liderança civil. Em segundo lugar, o fato de a luta armada ter passado a considerar-se uma escola, onde se ensinavam coisas fundamentais que não se podiam aprender nos livros. Portanto, na Frelimo, todos deviam lutar e todos deviam estudar. Finalmente, a importância crescente de uma linguagem tirada do socialismo revolucionário, embora com bases teóricas muito leves (Cahen, 2008, 2010; Macagno, 2009). Se Mondlane representava os contatos com América, a liderança de Machel ocupou o período de influência do bloco do leste, primeiro da China e depois da União Soviética, no palco da geopolítica africana (Cahen, 1985, 1988).

Seguindo a linha de pensamento uniformizadora iniciada por Mondlane, a nova direção da Frelimo estava convencida de que os moçambicanos estavam unidos por uma experiência colonial comum, e deviam manter-se unidos para conseguir derrotar o colonialismo. Levando essa perspectiva ao extremo, chega-se à conclusão de que as diferenças entre moçambicanos eram todas produto do colonialismo, que sempre aplicou a estratégia de dividir o inimigo para vencer.

Assim, a melhor resposta a esses conflitos era modelar uma nação unitária e uniforme, com uma identidade nacional que apagasse completamente as divisóes coloniais. Havia que matar a tribo para construir a nação, pois só destruindo completamente a herança colonial é que se podia conseguir alicerces firmes para um novo futuro (Magode, 1996). Havia as divisóes vindas da decadência das cidades, onde os vícios e o desrespeito destruíam as relaçóes familiares, deixando via livre ao individualismo (Casal, 1991). Era esse o caso dos africanos que ficavam ao lado do colonialismo para manter um emprego ou ganhar algum dinheiro no comércio, sem se importar que outros estivessem a lutar por sua liberdade. Havia também as divisôes vindas do obscurantismo e do tribalismo. Era o caso dos régulos habituados a explorar o povo por conta do imperialismo, como se fosse seu direito costumeiro — os que não queriam olhar para além dos limites dos seus regulados, pois achavam que não lhes dizia respeito.Por meio da experiência da luta, chegou-se finalmente à conclusão de que a superação dessas divisões só seria possível graças a um novo tipo de homem. O Homem Novo era pensado como aquele capaz de rejeitar conscientemente essas duas heranças coloniais, para construir uma sociedade mais justa. A metodologia visada para esse fim era a própria experiência da luta armada. Assim, a guerra não era só uma 
atividade militar destinada a derrotar o imperialismo, era também um processo de socialização onde se produziam novos cidadãos (Cabaço, 2001, 2010, 2012; Macagno, 2009). O povo em armas? Sim, mas era só depois de pegar nas armas e lutar que os combatentes se descobriam como povo, numa nova identidade.

Os campos de treino militar de Kongwe e Nachingwea, no sul da Tanzânia, e as zonas libertas no interior de Moçambique eram os locais onde esse processo de socialização estaria a funcionar a pleno rendimento. Ali se havia de produzir as camadas que, a médio prazo, encheriam o país com Homens Novos. Esse programa político, de um idealismo e um modernismo extremamente ingênuos e radicais, contava com uma luta armada de longa duraçáo (Brito, 2001). A duração da guerra, portanto, não podia ser motivo de desânimo; pelo contrário, era uma necessidade para atingir a independência em condiçôes de maioria social. Assim, o golpe dos capitães em Lisboa, em 25 de abril de 1974, foi uma dupla surpresa: por um lado, fez a independência muito mais próxima, mas por outro também obrigou a Frelimo a acelerar: havia que convencer a maioria da população moçambicana das bondades do seu projeto para Moçambique (Corrêa \& Homem, 1977).

Uma vez conseguida a independência, a realidade logo mostrou que governar a sociedade moçambicana, na sua diversidade social e regional, era bem mais complexo que governar um campo de treino militar. O romance de Luís Loforte (2006) O advogado de Inhassungue é uma reflexão sobre as violências que acompanharam a independência. A improvisada imposição de um modelo social idealizado e extremamente esquisito para a maioria dividiu ainda mais a sociedade moçambicana (Igreja, 2012, 2013). Logo a desestabilização produzida pela Rodésia e pela África do Sul veio a piorar um cenário social já complicado. Menos de dez anos depois da independência, até os mais teimosos tinham desistido do Homem Novo. O demógrafo moçambicano António Francisco descreveu o ambiente do terceiro congresso da Frelimo, em 1983, com estes versos do poeta Novalis: "Estamos pertos de despertar, quando sonhamos que sonhamos" (Francisco, 2003).

\section{A queda do Homem Novo}

A Frelimo desenvolveu, durante a luta de libertação (1964-1974), um modelo de sociedade muito idealista nos objetivos e muito rigorosa nas atitudes (valorização do esforço, condenação dos vícios etc.). O Homem Novo tinha um ar puritano, misto de educaçáo protestante de muitos dos dirigentes e disciplina militar. Finda a guerra, o método para confrontar os novos desafios da independência era repetido nos comícios do partido: "Disciplina, Trabalho, Vigilância. A luta continua!” (Corrêa \& Homem, 1977). 
Porém, foi só um pequeno grupo de pessoas, dentro da já mencionada diversidade de percursos reunidos na Frente de Libertação, os que desenvolveram esse modelo. Por sinal, um pequeno grupo bem relacionado com as redes internacionais de apoio às lutas anticoloniais - alguns mais próximos ao setor das igrejas protestantes, outros ao setor da esquerda internacional. No decorrer da luta armada e dos conflitos internos que a acompanhavam, esse grupo foi ganhando peso na estrutura de comando militar da Frelimo. Quando, em 1969, Mondlane foi assassinado, esse grupo expulsou seus principais oponentes sob acusação de traição e passou a liderar a Frelimo em solitário (Cahen, 2010). Então é que começou a sério a reflexão sobre o Homem Novo (Cabaço, 2001).

Dentro da Frelimo, esse pequeno grupo de dirigentes, saídos de um meio urbano, diferenciava-se do conjunto dos soldados, onde havia mais população rural, procedente das vizinhanças das zonas libertadas e majoritariamente analfabeta. Os dirigentes consideravam-se Homens Novos já realizados (Cabaço, 2001; Macagno, 2009); consideravam os guerrilheiros de incorporação mais recente como em processo de formação revolucionária, para algum dia serem Homens Novos; e, finalmente, havia os que continuavam vivendo nas trevas do mundo colonial. Do ponto de vista da Frelimo, os piores entre eles eram os que decidiram de própria vontade envolver-se nas instituições do colonialismo: régulos, soldados do exército colonial, funcionários civis, deputados provinciais, agricultores abastados etc.

Ora, o projeto de transformação social da maioria da população sob a liderança de uma minoria esclarecida — os Homens Novos — tinha muitas semelhanças com o projeto do assimilacionismo português, pois ambos acreditavam numa sorte de engenharia social que havia de melhorar a sociedade e se justificava pela superioridade cultural e moral dos dirigentes que a propunham. Contudo, havia também diferenças importantes entre o assimilacionismo e o Homem Novo. O conceito de inimigo interno é uma delas.

Do ponto de vista dos Homens Novos, eram inimigos internos todos os que haviam aceitado as regalias do colonialismo. Muitos destes estavam habituados tanto à vida urbana como à economia moderna, e os dirigentes da Frelimo receavam que agora pudessem aproveitar a independência, pela que náo lutaram, para ocupar o lugar dos portugueses que fugiam de Moçambique. Assim, muitos dos que não foram lutar eram vistos como a nova burguesia, apanhada a sair do ovo.

Acabada a guerra de libertação, as cidades continuavam sendo vistas como o núcleo do colonialismo, o berço do inimigo interno, e lugar das piores degradaçóes sociais, por exemplo o açambarcamento de mantimentos à procura de lucros econômicos, ou a promiscuidade sexual (Casal, 1991). A minoria de 
Homens Novos quis continuar a luta pela depuração das cidades. Agora era uma luta puritana: as prostitutas foram sistematicamente levadas a campos de reeducação (Corrêa \& Homem, 1977). Também muitos estudantes, de ambos os sexos, foram expulsos das escolas por gravidez náo desejada. Por outro lado, o casamento poligínico, próprio do centro e sul de Moçambique, apresentava-se como um exemplo típico de obscurantismo, do atraso da cultura africana. Pouco tempo depois da independência, houve várias expulsóes do comitê central da Frelimo por comportamentos sexuais considerados inaceitáveis (Morosini, 1982).

A diversidade nunca foi apreciada na Frelimo, mas depois da independência foi ainda mais suspeita de esconder o inimigo interno. Provavelmente, na euforia pela independência conseguida, e na urgência de agir para governar uma situação caótica como a que havia em Moçambique durante o governo de transição — de setembro de 1974 até junho de 1975 — e nos primeiros anos da independência, os Homens Novos não tiveram a possibilidade de avaliar como era minoritário seu programa de mudanças radicais. A maioria dos moçambicanos celebraram a vitória da Frelimo na luta pela independência, mas também é certo que não esperavam uma mudança radical de vida. Precisamente agora que finalmente tinha um Estado próprio, a maior parte da população queria simplesmente viver melhor e em paz. Mas o que a Frelimo lhe mandava era continuar a luta ${ }^{15}$ para derrotar um inimigo interno, cada vez mais onipresente (Igreja, 2012, 2013).

A direção da Frelimo não soube nem quis criar empatia procurando consensos no conjunto da sociedade, ou tentando integrar o maior número de setores sociais no seu projeto político. Pelo contrário, usou a supremacia moral que se atribuía - na condição de Homens Novos - para ridicularizar as atitudes da maioria da população. Foi um erro, pois perdeu o apoio de muitos setores que teriam sido chave para o sucesso de qualquer mudança social. Seria interessante aprofundar nas consequências políticas daquele erro, pois, se tivesse sido tratada com maior respeito, talvez muito mais gente teria aderido à revolução. Contudo, náo podemos saber o que teria acontecido. $\mathrm{O}$ que aconteceu foi um progressivo decréscimo da base social da Frelimo à medida que os erros se acumulavam. Aos erros próprios se juntaram os fatores externos (desestabilização provocada pelos regimes vizinhos, mais os efeitos combinados das secas e das cheias), o que logo levou ao desprestígio da Frelimo e dos valores a ela associados, principalmente no campo (Casal, 1988).

\section{Nova viragem: do Homem Novo a um novo tipo de exclusáo}

Samora faleceu, com toda a comitiva presidencial, num acidente de aviáo quando regressava da Zâmbia, em outubro de 1986. Uns anos antes, Moçambique 
havia começado uma nova aproximaçáo ao bloco ocidental, nomeadamente nos contatos com o Banco Mundial, o Fundo Monetário Internacional e o governo dos Estados Unidos (Francisco, 2003). Pressionado pela guerra interna, também havia assinado acordos com o regime do apartheid — Acordos do Incomáti de 1984 — mas essa iniciativa não deu os resultados esperados, pois a guerrilha que lutava contra o governo, a Resistência Nacional de Moçambique (Renamo), seguiu atuando com força, e cada vez mais espalhada pelo território moçambicano. Como tinha acontecido com Mondlane, a morte de Machel calhou num momento de profundas tensóes que anunciavam uma viragem dentro da Frelimo.

Uma vez decidido a abandonar a vida de enfermeiro para lutar pela independência, Machel foi chamado pela vocação militar (Ganhão, 2001) e teve orgulho da sua condição de guerrilheiro até a morte. Um bom militar está habituado a conseguir objetivos práticos, e a avaliar os riscos e os efetivos disponíveis. Talvez por isso Samora tenha previsto com assombrosa exatidão o que podia acontecer se o Homem Novo não conseguisse vingar na sociedade moçambicana: "mesmo quando destruídos os sistemas de exploração, se não combatermos a mentalidade que os determina, cedo ou tarde, lenta ou rapidamente, o sistema renascerá das suas cinzas fecundado pelos valores negativos que foram preservados em nós" (citado por Cabaço, 2001:141).

Com efeito, logo após a morte de Samora, as cinzas da mentalidade que o Homem Novo queria combater começaram a dar mostras de renascer. Hoje resulta evidente que aquela mentalidade nunca faleceu, simplesmente estava escondida à espera de melhores dias. Nos finais da década de 1980, a guerra em Moçambique estava numa das fases mais destrutivas. O Partido-Estado Frelimo estava isolado nas cidades, desligado da maior parte do território nacional, e Moçambique era considerado o país mais pobre do mundo pelos organismos internacionais. A quebra da produção agrícola era maciça (Casal, 1989), e havia o imperativo de melhorar a produção e a distribuição de alimentos para paliar a fome.

Porém, os membros do partido estavam impedidos de ser proprietários de meios de produção e de ter trabalhadores assalariados. Em meados de 1986, foi levantada no comitê central da Frelimo a questão da propriedade da terra. $\mathrm{O}$ debate que se seguiu mostrou que se estava formando uma nova maioria no interior da Frelimo, e no fim daquela reunião foi aprovado que o membro do partido podia ser proprietário e, se morava fora da cidade, assalariar até três trabalhadores nas suas terras (Cabaço, 2001). Também os antigos régulos foram chamados às funçôes de chefes de produção, nomeadamente em Nampula (Dinerman, 1999). Por outro lado, o exército moçambicano, na sua impotência 
para derrotar a Renamo, acabou por atuar de maneira não muito diferente de como havia feito o exército colonial português quando lutava contra a própria Frelimo (Borges Coelho, 2012; Brito, 2001).

Finalmente, nesse contexto de incerteza e mudanças radicais (Fry, 2000), também a velha categoria de indígena apareceu no debate. Paralelamente às mudanças econômicas e de regime político, um dos debates mais controversos no seio da Frelimo era sobre quem devia ser considerado cidadão moçambicano: a cidadania devia ser restrita aos chamados moçambicanos genuínos? E, se assim fosse, quem seriam os tais moçambicanos genuínos? O'Laughlin cita um dos depoimentos mais explícitos sobre o assunto da cidadania, feito por António Hama Thai, deputado na Assembleia Nacional, membro do comitê político da Frelimo, general veterano da guerra de libertação e antigo ministro da Defesa:

if I were to define who is of Mozambican origin, I will put it this way: The original Mozambican is anyone who in the colonial period was known as a native [indígena]. Of Mozambican origin is anyone who in the colonial period paid the hut tax. Of Mozambican origin is anyone whose ancestors or descendants were deported to Sao Tomé and Principe, to Angola and to other unknown places. And I would say more, of Mozambican origin are all those who did forced labour [chibalo], all those who after Gungunhana's defeat in 1895 were deported with him to Fourth Island or Third Island or wherever it was exactly, to die there far away, never more to father children of Mozambican origin (2000:6). ${ }^{16}$

Com essa declaração, Hama Thai estava a defender a primazia da cidadania moçambicana para os antigos indígenas. Não foi uma opinião isolada, pois desde entáo tem sido recorrente a suspeita de que brancos, indianos, chineses e outras minorias que nunca foram indígenas não podem ser totalmente confiados como moçambicanos, supostamente por contarem com outras ligaçóes e lealdades fora do país (Thomaz, 2002, 2012). Em junho de 2012, o economista moçambicano Joáo Mosca contribuiu para o debate com um artigo no semanário Savana, intitulado "A genuinidade do menino Peter" (Mosca, 2012).

$\mathrm{O}$ artigo pode dividir-se em duas partes. Na primeira, o autor foca na injustiça de duvidar da pertença a Moçambique das pessoas cujas famílias ali nascem e moram há várias geraçóes. $\mathrm{O}$ autor o faz por meio do exemplo imaginário do menino Peter, com ascendência em vários continentes, e das conversas que ele mantém com alguns dos colegas de escola sobre as origens das respectivas famílias. Até aqui, o autor não faz mais do que sublinhar a diversidade de Moçambique desde muito cedo; os constantes deslocamentos de população no interior do 
continente africano; a conexão com os fluxos demográficos do Oceano Índico e de mais além; e, em consequência de tudo isso, a dificuldade de alguém poder vir a apresentar-se como moçambicano mais genuíno que outros.

$\mathrm{Na}$ segunda parte do artigo, o autor adentra outro patamar. Continuando com o exemplo do menino Peter, apresenta nova série de conversas de crianças na escola, desta vez sobre assuntos muito mais restritos às conversas privadas — pois é sabido que as crianças repetem na escola o que ouvem em casa. Trata-se aqui das razóes pelas quais alguns novos ricos que se orgulham de ser moçambicanos genuínos querem justificar seu patrimônio, feito nas duas últimas décadas. No desenrolar das conversas imaginárias na escola, aparecem novas dúvidas, e as crianças, já em casa, perguntam aos pais sobre o que ouviram dizer os colegas. No pano de fundo, adivinha-se a controvérsia sobre como as empresas públicas passaram a mãos privadas de membros do partido Frelimo (Francisco, 2003; Macamo, 2014).

A ligação das duas conversas — da suposta genuinidade dos cidadãos, e da produção e uso de riqueza de um país — dá ao artigo de Mosca uma complexidade especial e muito profícua, pois levanta questôes novas, ou melhor, não ditas. Por exemplo, se a riqueza de um país deve vir de uns poucos, para ser tão ricos como outros, ou dos rendimentos do trabalho honesto de todas as pessoas. Ou se, para conseguir um país melhor, não seria a honestidade e o esforço o que devia ser genuíno. Finalmente, se o orgulho de ser moçambicano deveria vir dos resultados conseguidos coletivamente, ou dos que cada um procurou por si e para si, à custa dos demais.

No fundo, encontramos aqui, reformulado, o velho problema do trabalho e da exclusão social da maioria dos moçambicanos, a mentalidade que alimenta os sistemas de exploração regime político após regime. Ora, teria Albasini entendido o artigo de Mosca? Claro que não, pois tudo se complicou tanto que ficou irreconhecível. Os régulos de que Albasini falava têm pouco a ver com os que foram empossados pela Frelimo já no século XXI, depois da aprovação do Decreto-Lei 15/2000 (Farré, 2006, 2008). De assimilados já não se fala, pois já há quarenta anos que são moçambicanos, identidade que Albasini nunca imaginou. Os indígenas, já vimos que foram recuperados por uma elite que se quer genuína. Em suma, do legalismo de um quebra-cabeça colonial feito de peças que náo encaixam, passou-se ao idealismo redentor do Homem Novo, e daí ao materialismo luxuriante de certas elites atuais. Todos muito diferentes, e todos tentando ultrapassar as heranças recebidas. Entretanto, a exclusão da maioria continua no centro dos projetos políticos. No artigo de Mosca, as crianças acabam por fazer greve contra as confusóes dos pais, exigindo que as deixem estudar 
tranquilas para fazer um país melhor para todos. $\mathrm{Na}$ minha interpretação, essa greve imaginária tem muito a ver com a necessidade de abandonar o hábito dos poderosos de excluírem a outros moçambicanos.

Recebido em 27/08/2015.

Aceito em 27/09/2015.

Albert Farré é doutor pela Universidade de Barcelona (2005) com uma tese sobre as relações entre o Estado e as populações rurais em Moçambique. Tem feito trabalho de campo etnográfico em Moçambique, Uganda e República Democrática no Congo. Nos três casos, tem trabalhado com comunidades rurais em período de pós-guerra. Foi investigador de pós-doutorado no ISCTE-IUL de Lisboa (2006-2011), e também no Human Economy Programme da Universidade de Pretória (2012-2013). Atualmente é investigador colaborador (PNPD-Capes) no PPGAS da Universidade de Brasília. Contato: fantura2@hotmail.com

\section{Notas}

1. O centro político português em Moçambique sempre foi a Ilha de Moçambique, no norte do país. Mas em 1898 foi transferido para o extremo sul, como consequência da nova importância estratégica da baía de Lourenço Marques como o porto mais próximo de Joanesburgo. A mudança da capital, $2.000 \mathrm{~km}$ para o sul, diminuiu a influência das famílias crioulas do norte, que ficaram afastadas do novo centro de poder. Essa situação teve consequências importantes para a estruturação do Estado colonial em Moçambique, diferenciando-o de Angola, onde Luanda se manteve como centro político. Já bem entrado o século XX, a Guiné também experimentou uma mudança de capital, de Bolama a Bissau, mas não é comparável com o rápido crescimento de Lourenço Marques depois da conexão ferroviária com Joanesburgo em 1895 (Lemos, 1995).

2. A migração de trabalhadores moçambicanos às minas inaugurou o debate acadêmico internacional sobre Moçambique, confrontando as opinióes do antropólogo americano Marvin Harris $(1959,1960)$ e do acadêmico e funcionário colonial António Rita-Ferreira (1960, 1961). Alice Dinerman (1999), José Luis Cabaço (2012) e Valdemir Zamparoni (2012) têm focado na relação entre trabalho, régulos e indígenas. Sobre o indigenato em Moçambique, destacamos o debate entre Bridget O'Laughlin (2000) e Mahmood Mamdani (2000). 
3. Numa outra ocasiáo, abordei as consequências desse longo processo de bricolagem. Este artigo pode considerar-se uma continuação, mais elaborada, do argumento esboçado naquela comunicação (Farré, 2014a).

4. Os membros de destaque foram António Enes, Mouzinho de Albuquerque, Eduardo da Costa, Aires de Ornellas, Freire de Andrade, e Paiva Couceiro. Sobre as especificidades do pensamento de cada um deles, ver Farré (2005).

5. Mikael Karlström (2004) foca no uso colonial da metáfora biológica da maturação referida às sociedades africanas. Gonçalo Duro dos Santos (2005), por seu lado, trata da hegemonia da antropologia física no pensamento colonial português. Os dois salientam o uso de modelos vindos das ciências naturais para serem aplicados às sociedades africanas. Karlström destaca também como setores cristianizados das sociedades africanas começaram a pensar-se, eles próprios, nos mesmos termos.

6. A Reforma Administrativa Ultramarina de 1933 estabelece o nome de regedor para um escaláo preciso do funcionalismo colonial em todo o Império, mas na prática o nome mudava segundo o território. Em Moçambique, os regedores eram chamados régulos.

7. Em alguns relatórios, os funcionários coloniais aceitam que, na hora de empossar um régulo, o mais importante é escolher um não muito comprometido com os interesses das populaçóes (Ferreira de Almeida, 1957).

8. Para além dos régulos, as lideranças muçulmanas foram alvo da ação psicológica (Monteiro, 2014).

9. $\mathrm{O}$ que não quer dizer que não houvesse autoridades cuja fonte de poder viesse das sociedades africanas. Mas a maioria, pelas responsabilidades exigidas à sua posição, optou pela discrição: quanto menos os portugueses suspeitassem da sua existência, mais podiam eles dedicar seus esforços a fazer o que lhes correspondia.

10. Assim eram considerados oficialmente os que pegaram nas armas para lutar pela independência. Na fala popular, eram chamados de turras.

11. Ora, que tal possibilidade existisse náo quer dizer que todos o conseguissem. A política rural estava recheada de complexidades locais: rivalidades, concorrências, ciúmes, oportunismos e demais armadilhas do passado que os régulos coloniais nem sempre sabiam gerir.

12. Havia também companhias privadas, algumas das quais (com destaque na Zambézia: Madal, Boror, Sena Sugar States etc.) atuavam como verdadeiros Estados dentro do Estado. Nesse caso, o espaço de manobra dos régulos era muito menor.

13. Na década de 90, esta ligação deu aço a um dos debates mais longos e complexos do pós-guerra em Moçambique (Alexander, 1997; Cahen, 2008; Dinerman, 1994, 1999, 2009; Farré, 2006; Florêncio, 2005; Fry, 2000; Geffray, 1990, Harrison, 1996; Kyed \& Buur, 2006; Meneses et al., 2003; O’Laughlin, 1992, 2000; West, 2008, 2009).

14. As pessoas tentaram refundar os antigos partidos ou fundar outros novos. Contudo, a Frelimo manteve-se a organização mais forte e estruturada (Cahen, 2010). 
$\mathrm{Na}$ altura de negociar a independência, em 1974, a Frelimo conseguir ser considerada a única representante do povo moçambicano.

15. Referência ao famoso slogan revolucionário "A luta continua".

16. Não consegui consultar o texto original em português, "Quem é moçambicano e quem não é?”, publicado no jornal Notícias em 10 de outubro de 1990, e preferi não traduzir de novo ao português por ser mais um risco de afastamento do original.

\section{Referências bibliográficas}

ADAM, Yussuf. 1993. "Mueda, 1917-1990: resistência, colonialismo, libertação e desenvolvimento". Arquivo, 14:9-103.

2006. Cooperativização na agricultura e relaçóes de produção em Moçambique.

Maputo: Promédia.

ADAM, Yussuf \& GENTILI, Ana Maria. 1983. "O movimento dos Liguilanilu no Planalto de Mueda, 1957-1962”. Estudos Moçambicanos, 4:41-75.

ALEXANDER, Jocelyn. 1997. "The local state in post-war Mozambique: political practice and ideas about authority". Africa: Journal of The International African Institute, 67(1):1-26.

BORGES COELHO, João Paulo. 2010. O olho de Hertzog. Lisboa: Leya.

- 2012. “Tropas negras na guerra colonial em Moçambique”. In: Cláudia

Castelo et al. (orgs.). Os Outros da colonizaçâo: ensaios sobre o colonialismo tardio em Moçambique. Lisboa: ICS. pp. 303-314.

BRITO, Luis de. 1988. "Un relecture necessaire: la genèse du parti-État FRELIMO". Politique Africaine, 29:15-17.

. 2001. "O poder entre a utopia e a realidade". In: António Sopa (ed.). Samora: homem do povo. Maputo: Maguezo. pp. 39-46.

. 2014. "Uma reflexão sobre o desafio da paz em Moçambique”. In: Sérgio Chichava et al. (orgs.). Desafios para Moçambique 2014. Maputo: IESE. pp. 23-39.

CABAÇO, José Luis. 2001. "O homem novo: breve itinerário de um projecto. In: António Sopa (ed.). Samora: homem do povo. Maputo: Maguezo. pp. 137-146.

Marimbique.

2010. Moçambique: identidades, colonialismo e libertação. Maputo: 
CABAÇO, José Luis. 2012. "Trabalho, colonialismo e pós-colonialismo em Moçambique". In: Cláudia Castelo et al. (orgs.). Os Outros da colonizaçâo: ensaios sobre o colonialismo tardio em Moçambique. Lisboa: ICS. pp. 155-170.

CAHEN, Michel. 1985. "État et pouvoir populaire dans le Mozambique independant". Politique Africaine, 19:36-60.

. 1988. "La crise du nationalisme". Politique Africaine, 29:2-14.

. 2008. "À la recherche de la défaite: notes sur une certaine historiographie de la 'révolution' et de la 'contre-révolution' au Mozambique et sans doute ailleurs". Politique Africaine, 112:161-181.

. 2010. "Moçambique: o fim da história... única. Trajectórias dos anticolonialismos em Moçambique”. Africana Studia, 15:195-240.

CASAL, Adolfo Y. 1988. "A crise de produção familiar e as aldeias comunais em Moçambique”. Revista Internacional de Estudos Africanos, 8-9:157-191.

- 1991. "Discurso socialista e camponeses africanos: legitimação políticaideológica da socialização rural em Moçambique (FRELIMO 1965-1984)". Revista Internacional de Estudos Africanos, 14-15:35-76.

CASTELO, Cláudia. 1999. "O modo português de estar no mundo": o luso-tropicalismo e a ideologia colonial portuguesa (1933-1961). Porto: Afrontamento.

.2004. “'Um segundo Brasil ou um terceiro Portugal': políticas de colonização branca da África Portuguesa”. Travessias, 4/5:155-180.

COISSORÓ, Narana. 1965. "O regime das terras em Moçambique". In: V.V.A.A., Moçambique: curso de extensão universitária. Ano lectivo de 1964-1965. Lisboa: Universidade Técnica de Lisboa/Instituto Superior de Ciências Sociais e Política Ultramarina. pp. 367-435.

CORRÊA, Sónia \& HOMEM, Eduardo. 1977. Moçambique: primeiras Machambas. Rio de Janeiro: Margem.

CORREIA, Milton. 2015. "A formação social do Estado-Nação e a crítica pós-colonial: o surgimento da história crítica em Moçambique”. Outros Tempos, 12(19):93-117.

COVANE, Luis António. 2001. O trabalho migratório e a agricultura no Sul de Moçambique (1920-1992). Maputo: Promédia.

CRUZ e SILVA, Teresa. 1990. "A 'IV Região' da Frelimo no Sul de Moçambique: Lourenço Marques 1964-65”. Caderno de Estudos Africanos, 8:125-142. 
1993. "Dois episódios da vida de Eduardo Mondlane, narrados por Pedro Demony". Caderno de Estudos Africanos, 13:159-168.

1999. "A missão suíça em Moçambique e a formação da juventude: a experiência de Eduardo Mondlane (1930-1961)”. Estudos Moçambicanos, 16:67-104.

2001. Igrejas protestantes e consciência politica no sul de Moçambique: o caso da Missão Suiça (1930-1974). Maputo: Promédia.

. 2004. "Identidade religiosa e construção da democracia em Moçambique: o caso da Igreja Metodista Unida de Moçambique”. Travessias, 4/5:223-235.

DINERMAN, Alice. 1994. "In search of Mozambique: the imaginings of Christian Geffray in La Cause des Armes au Mozambique. Anthropologie d'une Guerre Civile". Journal of Southern African Studies, 20(4):569-586.

. 1999. "O surgimento dos antigos régulos como 'chefes de produçáo' na província de Nampula (1975-1987)”. Estudos Moçambicanos, 17:95-256.

2009. "Regarding totalities and escape hatches in Mozambican politics and Mozambican Studies”. Politique Africaine, 113:187-210.

DIREITO, Bárbara. 2013. "Land and colonialism in Mozambique policies and practice in Inhambane, c.1900-c.1940”. Journal of Southern African Studies, 39(2):353-369.

FARRÉ, Albert. 2004. "O quebra-cabeças da legislação colonial: indígenas, portugueses e assimilados. Diferentes conceitos de pessoa em conflito (1901-1961)". IV Conferência Internacional de História de África, Maputo.

2005. Estat modern i llinatges locals a Moçambic: els discursos de la legitimitat en una història d'imatges distorsionades $i$ expectatives incomplertes. Tese de Doutorado, Universidade de Barcelona.

2006. "El debate sobre las autoridades llamadas tradicionales en Mozambique". Nova África, 18:75-85.

2008. "Vínculos de sangue e estruturas de papel: ritos e território na história de Quême (Inhambane)”. Análise Social, 43(2):393-418.

. 2010. "El poder y las autoridades tradicionales africanas". Janus: Meio Século de Independências Africanas, (13):128-129.

. 2014a. "Os Frankensteins africanos: categorias que já foram coloniais". Comunicaçẫo apresentada na 29a Reunião Brasileira de Antropologia. 
FARRÉ, Albert. 2014b. "Regime de terras e cultivo de algodão em dois contextos coloniais: Uganda e Moçambique (1895-1930)”. In: José Vicente Serrão, Bárbara Direito, Eugénia Rodrigues \& Susana Münch Miranda (eds.). Property rights, land and territory in the European overseas empires. Lisbon: CEHC-IUL. pp. 245-254.

. 2015. "Las mujeres y el mito de la agricultura de subsistencia: de la exportación de alimentos a la dependencia alimentaria en el sur de Mozambique". Cadernos de Estudos Africanos, 29:31-58.

FERREIRA DE ALMEIDA, Eugénio. 1957. Governo do distrito de Moçambique: relatório. Nampula, Lisboa: Agência Geral do Ultramar. 2 v.

FLORÊNCIO, Fernando. 2005. Ao encontro dos Mambos: autoridades tradicionais vaNdau e Estado em Moçambique. Lisboa: ICS.

FRANCISCO, António. 2003. "Reestruturação económica e desenvolvimento". In: Boaventura de Sousa Santos \& João Carlos Trindade (orgs.). Conflito e transformação social: uma paisagem das justiças em Moçambique. Porto: Afrontamento. pp. 141-178.

FRY, Peter. 2000. "Cultures of differences: the aftermath of Portuguese and British colonial policy in Southern Africa”. Social Anthropology, 8(2):117-143.

GANHÃO, Fernando. 2001. "Samora Machel: um relâmpago no céu”. In: António Sopa (ed.). Samora: homem do povo. Maputo: Maguezo. pp. 11-22.

GEFFRAY, Christian. 1990. La cause des armes au Mozambique. Paris: Karthala.

HARRIS, Marvin. 1959. "Labour emigration among the Mozambique Thonga: cultural and political factors". Africa: Journal of the International African Institute, 29(1):50-66.

1960. "Labour emigration among the Mozambique Thonga: a reply to Sr. Rita-Ferreira”. Africa: Journal of the International African Institute, 30(3):243-345.

HARRISON, Graham. 1996. "Democracy in Mozambique: the significance of multyparty elections". Review of African Political Economy, 67:19-35.

. 1998. "Marketing legitimacy in rural Mozambique: the case of Mecufi District, Northern Mozambique". The Journal of Modern African Studies, 36(4):569-591. HELGESSON, Alf. 2002. Church, state and people in Southern Mozambique: an historical study with special emphasis on Methodist developments in the Inhambane region. Uppsala: Studia Missionalia Uppsaliensia.

IGREJA, Victor. 2012. "Frelimo's political ruling through violence and memory in postcolonial Mozambique”. Journal of Southern African Studies, 36(4):781-799. 
2013. "Politics of memory, decentralization and recentralization in Mozambique". Journal of Southern African Studies, 39(2):313-335.

JOÃO, Benedito Brito. 2000. Abdul Kamal e a história de Chiúre nos séculos XIX X XX: um estudo sobre as chefias tradicionais, as redes islâmicas e a colonização portuguesa. Maputo: Arquivo Histórico de Moçambique. (Estudos, 17).

KARLSTRÖM, Mikael. 2004. "Modernity and its aspirants: modern community and developmental Eutopianism in Buganda". Current Anthropology, 45(5):595-611.

KYED, Helena Maria \& BUUR, Lars. 2006. "New sites of citizenship: recognition of traditional authority and group-based citizenship in Mozambique". Journal of Southern African Studies, 32(3):563-581.

LEMOS, M. J. C. 1995. "Relaçôes de Lourenço Marques com o Transvaal, antes e depois da ligação ferroviária”. Boletim do Arquivo Histórico de Moçambique, 17:87-124.

LÉVI-STRAUSS, Claude. 1971. El pensament selvage. Barcelona: Edicions 62.

LOFORTE, Luis. 2006. O advogado de Inhassungue. Lisboa: Quetzal.

LYRA, Maria de Lourdes Viana. 1994. A utopia do poderoso império: Portugal e Brasil: bastidores da politica 1798-1822. Rio de Janeiro: Sete Letras.

MACAGNO, Lorenzo. 2001. "O discurso colonial e a fabricação dos usos e costumes. António Enes e a 'geração do 95”'. In: Peter Fry (org.). Moçambique: ensaios. Rio de Janeiro: UFRJ. pp 61-90.

. 2009. "Fragmentos de uma imaginação colonial". Revista Brasileira de Ciências Sociais, 24(70):17-35.

. 2012a. "Os 'chineses' da Beira, Moçambique: itinerários de uma dispersão". In: Juliana Braz Dias \& Andréa de Souza Lobo (orgs.). África em movimento. Brasília: ABA. 177-199.

.2012b. "Franz Boas e Kamba Simango: epistolários de um diálogo etnográfico". In: Wilson Trajano Filho (org.). Travessias antropológicas: estudos em contextos africanos. Brasília: ABA. pp. 127-158.

MACAMO, Elísio. 2014. "Cultura política e cidadania em Moçambique: uma relação conflituosa”. In: Sérgio Chichava et al. (orgs.). Desafios para Moçambique 2014. Maputo: IESE. pp. 41-60.

MAGODE, José (ed.). 1996. Moçambique: etnicidades, nacionalismo e o Estado. Transiçāo inacabada. Maputo: CEEI. 
MAMDANI, Mahmood. 1996. Citizen and subject: contemporary Africa and the legacy of late colonialism. Princeton.

. 2000. "Indirect rule and the struggle for democracy: a response to Bridget O’Lauglin”. African Affairs, 99:43-46.

MARGARIDO, Alfredo. 1988. "Literature et nationalité". Politique Africaine, 29:58-70.

MENESES, Maria Paula; FUMO, Joaquim; MBILANA, Guilherme \& GOMES, Conceição. 2003. "As autoridades tradicionais no contexto do pluralismo jurídico". In: Boaventura de Sousa Santos \& João Carlos Trindade (orgs.). Conflito e transformação social: uma paisagem das justiças em Moçambique. Porto: Afrontamento. v. 2, pp. 341-420.

MONTEIRO, Fernando Amaro. 2014. Eu vivi a queda do império: factos e personagens verídicos. Lisboa: Letras Itinerantes.

MOREIRA, Adriano. 1960. Ensaios. Lisboa: Junta de Investigaçóes do Ultramar. Estudos de Ciências Políticas e Sociais, 34.

MOREIRA, José. 1997. Os assimilados: João Albasini e as eleições, 1900-1922. Maputo: Arquivo Histórico de Moçambique. (Estudos, 11).

MOROSINI, Giusseppe. 1982/1983. "État, parti et nation dans le Mozambique independant". Civilizations, 32/33:135-152.

MOSCA, João. 2012. "A genuinidade do menino Peter". Semanário Savana, 13 jun. 2012. p. 7.

NEWITT, Malyn. 1997. História de Moçambique. Lisboa: Publicaçôes Europa-América.

NGOENHA, Severino. 1993. Filosofia africana: das independências às liberdades. Maputo: Ediçóes Paulistas.

O’LAUGHLIN, Bridget. 1992. "A base social da guerra em Moçambique". Estudos Moçambicanos, 10:107-142.

. 2000. "Class and the customary: the ambiguous legacy of the indigenato in Mozambique”. African Affairs, 99:5-42.

OPELLO, Walter. 1975. "Pluralism and elite conflict in an Independence Movement: Frelimo in the 1960s". Journal of Southern African Studies, 2(1):66-82.

PENVENNE, Jean Marie. 1989. "'We are all Portuguese!' Challenging the political economy of assimilation: Lourenço Marques 1870-1933". In: Leroy Vail (ed.). The creation of tribalism in Southern Africa. London: James Currey. pp. 255-289. 
. 1996. "João dos Santos Albasini (1876-1922): the contradictions of politics and identity in colonial Mozambique". The Journal of African History, 37(3):419-464.

PINA CABRAL, João de. 2000. "Galvão na terra dos canibais: a constituição emocional do poder colonial”. Novos Estudos/CEBRAP, 57:124-140.

2002. "Dona Berta's garden: reaching across the colonial boundary". Etnográfica, 6(1):77-91.

. 2004. "Cisma e continuidade em Moçambique". In: Clara Carvalho \& João de Pina Cabral (orgs.). A persistência da história. Lisboa: ICS. pp. 375-392.

2005. "Rios e estaçôes: solidariedades primárias e preteridade em Moçambique”. In: Manuel Villaverde Cabral, José Luis Garcia \& Helena Jerónimo (orgs.). Razão, tempo e tecnologia: estudos em homenagem a Herminio Martins. Lisboa: ICS. pp. 197-225.

RITA-FERREIRA, António. 1960. "Labour emigration among the Mozambique Thonga: comments on a study by Marvin Harris". Africa: Journal of the International African Institute, 30(2):141-152.

. 1961. "Labour emigration among the Mozambique Thonga: comments on Marvin Harris's Reply”. Africa: Journal of the International African Institute, 31(1):75-77.

SANSONE, Lívio. 2013. "Eduardo Mondlane e as ciências sociais". In: Wilson Trajano Filho (org.). Travessias antropológicas: estudos em contextos africanos. Brasília: ABA. pp. 93-126.

SANTOS, Gonçalo Duro dos. 2005. A Escola de Antropologia de Coimbra 1885-1950. Lisboa: ICS.

SILVA, Calane da. 2007. "Rui de Noronha: o poeta-cronista da nossa 'causa sagrada"”. In: António Sopa, Calane da Silva \& Olga Iglésias Neves (orgs.). Rui de Noronha, Ao mata-bicho. Textos publicados no semanário O Brado Africano. Maputo: Texto Editores.

SIMÓES DO PAÇO, António (ed.). 2008. Os anos de Salazar, vol. 18. 1961: o ano de todos os perigos. Lisboa: PDA.

TEIXEIRA, José. 2004. "Ma-tuga no mato: os 'portugueses' em discursos rurais moçambicanos”. In: Clara Carvalho \& João de Pina Cabral (orgs.). A persistência da história: passado e contemporaneidade em África. Lisboa: ICS. pp: 307-341.

THOMAZ, Omar Ribeiro. 2002. "Raça', nação e status: a guerra e as 'relações raciais' em Moçambique”. Revista USP, 68:252-268. Disponível em: http://www.usp.br/ revistausp/68/19-omar-ribeiro.pdf. Acesso em: 23/03/2015. 
THOMAZ, Omar Ribeiro. 2012. "Nem Rodésia nem Congo: Moçambique e os dias do fim das comunidades de origem europeia e asiática". In: Cláudia Castelo et al. (orgs.). Os Outros da colonização: ensaios sobre o colonialismo tardio em Moçambique. Lisboa: ICS. pp. 315-340.

TOULMIN, Stephen. 2001. Cosmópolis: el trasfondo de la modernidad. Barcelona: Península.

TRAJANO FILHO, Wilson. 2004. "A constituição de um olhar fragilizado: notas sobre o colonialismo português em África”. In: Clara Carvalho \& João de Pina Cabral (orgs.). A persistência da história: passado e contemporaneidade em África. Lisboa: ICS. pp. 21-59. WEST, Harry G. 2008. “'Governem-se vocês mesmos!' Democracia e carnificina no Norte de Moçambique”. Análise Social, 43(2):347-368.

. 2009. Kupilikula: o poder e o invisivel em Mueda, Moçambique. Lisboa: ICS.

ZAMPARONI, Valdemir. 2000. "Monhés, Baneanes, Chinas e Afro-Mahometanos: colonialismo e racismo em Lourenço Marques, Moçambique 1890-1840". Lusotopie: 191-222.

2012. De escravo a cozinheiro: colonialismo e racismo em Moçambique. Salvador: Edufba-Ceao. 


\section{Resumo}

Independentemente do regime Despite radical shifts in the political político, a exclusão social tem sido uma system, social exclusion has been constante em Moçambique. O artigo a common and everyday fact in propóe uma análise das categorias Mozambique. In this article, we look sociais desenvolvidas pelo colonialismo at colonial ways of social classification português nos inícios do século XX, e developed by Portuguese colonialism do seu percurso através dos diferentes debates e projetos políticos que os moçambicanos viveram, tanto durante o período colonial como depois da independência. $\mathrm{O}$ artigo procura explicar por que categorias tipicamente coloniais, como régulo ou indígena, reapareceram nos debates de finais do século $\mathrm{XX}$, em pleno processo de transição para a democracia e $o$ capitalismo.

Palavras-chave: colonialismo; cidadania; democracia; Frelimo; moçambicanidade.

\section{Abstract} century, and how they evolved through the several debates and political projects launched during and after colonialism. We propose an explanation to why typically colonial concepts, such as régulo (paramount chief) or indigena (native), reappeared in the social debates of the 1990s, in a context of political transition towards multi-party democracy and capitalism.

Keywords: colonialism; citizenship; democracy; Frelimo; Mozambicanity. 